\title{
Phytoremediation of Lebanese polluted waters: a review of current initiatives
}

\author{
Hassana Ghanem ${ }^{1, *}$, Lamis Chalak $^{2}$, and Safaa Baydoun $^{3}$ \\ ${ }^{1}$ Biology Department, Faculty of Sciences, Beirut Arab University, Debbieh, Lebanon \\ ${ }^{2}$ Plant Production Department, Faculty of Agronomy, Lebanese University, Beirut, Lebanon \\ ${ }^{3}$ Research Center for Environment and Development, Beirut Arab University, Bekaa, Lebanon
}

\begin{abstract}
Water pollution is presently considered as a serious apprehension in Lebanon. Heavy contamination load of nutrients, heavy metals and organic pollutants can be highly harmful for human health and detrimental to aquatic life and ecosystems. Phytoremediation in natural and constructed wetlands using aquatic macrophytes present a sustainable plant-based technology recognized as a very efficient option in water treatment. The employment of species such as Phragmites, Sparganium, Lemna sp and other aquatic macrophytes not only helps in pollution cleanup but also conserves aquatic communities. To date, two pilot constructed wetlands, Litani River and Bcharreh have been established in Lebanon. These promising initiatives have been, however, accompanied with very limited research studies to examine the role of utilized plants and their efficiency in the remediation process. This paper presents an overview of the status of these initiatives and phytoremediation potential in Lebanon.
\end{abstract}

\section{Introduction}

Rapid urbanization, industrialization, and use of agrochemicals have resulted in major pollution problems of aquatic environments. Water pollution can cause serious problems to human health and wellbeing leading to complex socioeconomic adverse impacts [1]. Some water pollutants are highly persistent, whereas others break down by chemical and biological degradation processes [2]. The U.S. Environmental Protection Agency (EPA) estimates that $46 \%$ of the world water bodies are polluted and non appropriate to human use [3]. Freshwater biodiversity recessed by $81 \%$ between 1970 and 2012 due to pollution, overexploitation and deterioration of water bodies [4]. The global economic cost of the lack of clean water is estimated to exceed billions of dollars yearly [1]. Excessive nutrients discharge into surface water bodies leads to a process known as eutrophication. This phenomenon is characterized by excessive plant and algal growth and reported to cause impairment of many aquatic ecosystems in the world [5]. The release of various algal toxic substances and pathogenic microorganisms namely fecal coliform bacteria can cause serious adverse impact on public health and consequently impeding livelihood and economic development [2, 5]. At least half the world's population suffers from polluted water and millions of people are deceased every year due to water-borne diseases [1].

Given the envisaged increase in anthropogenic pressure along with climate change projections, contamination of aquatic ecosystems will likely intensify unless sustainable management approaches are efficiently practiced. Related water pollution-reducing targets in the UN 2030 Sustainable Development Goals highly reflect the flourishing international consideration on water quality and environmental deterioration being among the most extensive challenges presently facing humanity. Specifically, SDG 6 "Ensure availability and sustainable management of water and sanitation for all" perceives that community progress and economic wealth depend on the feasible management of freshwater resources and ecosystems [6].

In response, conventional remediation systems based on high physical and chemical approaches have been developed to restore both soil and water polluted sites [7,8]. The processes involved in removing the contaminants include physical processes such as settling and filtration, and chemical processes such as disinfection and coagulation. Much of these conventional remediation methods are efficient but economically costly and non-feasible. Thus, there has been a growing interest in the search for alternative or complementary remediation technologies such as phytoremediation that is efficient, cost-effective and durable.

Phytoremediation describes the ability of plants to remove, uptake or stabilize the contaminants in air, water, sediments, or soils [7,9]. The term phytoremediation (phyto $=$ plant and remediation $=$ correct an evil) is relatively recent with most studies being conducted mostly during the last two decades (1991 onwards). Plants based environmental remediation technology has been widely accepted by academic and industrial scientists as a sustainable and applicable cleanup option. Much progress has been made in USA, China, India and European countries [9-14]. In the Near East, phytoremediation trials were conducted in Jordan, Egypt and Iraq for the remediation of wastewater and heavy metals from polluted lakes and streams [15-20].

* Corresponding author:hassanaghanem@hotmail.com 
Phytoremediation efficiency varies among geographic and climatic conditions, and types of pollution [8]. It is still in its very early stages in many developing countries where heavy pollution load continues to be delivered into water bodies [20]. This is the case of Lebanon where water bodies have been severely impacted by human activities during recent decades. Effluent discharge, extensive use of agricultural chemicals along with increased demand and heavy exploitation of water resources have led to severe quality deterioration affecting life quality of local inhabitants and adversely impacting economy [21]. In 2000, the cost of water degradation in the Lebanese polluted water bodies was estimated at about US\$120 million per year or 0.71 percent of annual GDP [22]. Therefore, the implementation of sustainable remediation such as phytoremediation is essential to combating water pollution and associated consequences.

In this paper, we aim to review the importance of phytoremediation processes and application modes worldwide, and then address the status of phytoremediation initiatives of polluted fresh surface waters of Lebanon. A literature survey covering research publications and reports was performed. The study is hoped to contribute to promoting phytoremediation option and its use in polluted water and wastewater treatment in the country.

\section{Phytoremediation}

Phytoremediation is the use of plants to dispose of environmental pollutants as an efficient remediation tool for organic and inorganic contaminants [23]. This technology follows the naturally occurring processes by which plants and their microbial rhizosphere flora degrade and sequester organic and inorganic pollutants. Phytoremediation has gained rising consideration since last decade, as a promising cost effective technology [23]. It includes many techniques distinct with the form of pollutants plant species can target (organic or inorganic contaminant) [24]. Various aquatic plants, also called macrophytes, naturally present in an aquatic ecosystem, are well-known for their ability to uptake nutrients, heavy metals and other pollutants [24].

The mechanisms and efficiency of phytoremediation depend on the type of contaminant, bioavailability and aquatic biodiversity [11]. Plants can be used in various ways to prevent or remediate environmental pollution [23]. The uptake of pollutants in plants arises through the root system which provides an enormous surface area for uptakes and exhibits high accumulation capacity of nutrients and pollutants [11]. Plants can degrade pollutants inside their tissues; this method is called phytodegradation and is mostly suitable for organic pollutants. In some cases the pollutant is immobilized in the root zone, which is called phytostabilization leading to reducing the mobility and bioavailability of metals and thus preventing their uptake by other aquatic organisms and through the food chain. Being mostly used for inorganics, phytoextraction is the uptake of pollutants by roots and their translocation and accumulation in harvestable plant biomass, particularly shoot tissues. Rhizofiltration is another mechanism when plant accumulation or adsorption is mainly made by plant roots in hydroponic systems. Some pollutants can also be volatilized by plants; this is known as phytovolatilization [23].

\section{Natural and constructed wetlands in phytoremediation}

Contaminants from domestic, agricultural and industrial wastes are directly or indirectly discharged into aquatic ecosystems. Natural wetlands have been naturally improving water quality through the presence of a diversity of aquatic plants and their associated flora and fauna. Constructed wetlands (CWs) are engineered aquatic structures that are used to get rid of hazardous wastes from contaminated water body under a more controlled environment [8]. Constructed wetlands are engineered swamplands intended to take advantage of the natural processes involving wetland vegetation, soils and associated microbial assemblages to treat wastewaters [13]. Wetlands are distinguished by some aspects including the presence of water, substrate, and diversity of macrophytes [24]. Consequently, the efficiency of the wetland system in phytoremediation and/or the competence of the macrophytes can be affected by different climatic conditions, soil type or aquatic biodiversity [25]. Both natural and constructed wetlands are worldwide considered as a cost-effective and an alternative technology for polluted water and wastewater treatment, they have been increasingly used to successfully remove pollutants from domestic and industrial effluents [11, 14, 26, 27]. Macrophytes used in phytoremediation in CW systems can diverge to various types based on their adaptations to life in water. On the other hand, wetlands provide a surface and an environment for microorganisms to grow. This stimulates both aerobic decomposition of organic matter and the growth of nitrifying bacteria [10].

\subsection{Macrophytes for phytoremediation}

Phytoremediation through the use of macrophytes, is increasingly applied in order to remediate nutrients and hazardous metals from eutrophic water sources [2, 7-9]. Such plant species have the ability to extract and accumulate, transform, degrade, or volatilize contaminants at levels that are toxic to common plants [11,28]. Cattail, reeds and rush are examples of emergent plants (Phragmites sp., Phalaris sp. and Typha sp.). Submerged species are plants that live under the surface of the water and nearly rooted in the sediments such as Ceratophyllum demersum and Myriophyllum spicatum. Floating plants include free floating and floating-leaved plants such as Eichhornia crassipes, Lemna sp, and Azolla sp. [24, 27, 29]. Wetland plants can take up heavy metals and nutrients through root systems and accumulate them in the biomass reducing therefore the concentrations of these polluting elements. The common reed (Phragmites australis) and cattail (Typha angustifolia) can uptake and accumulate a large amount of nutrients and heavy metals in their below and above water 
surface plant parts $[13,26,30]$ (Table 1). In CWs, phytoremediation plant species are able to absorb multiple pollutants simultaneously because pollution rarely occurs as a single chemical and grow fast [11]. In addition to their nutrients and heavy metals uptake, macrophytes possess other efficiencies that can be helpful in pollution remediation. Aquatic plants can represent a physical barrier to flow and act as a biofilter for suspended particles. Roots can provide an oxygenated microclimate which will be an excellent niche for microorganisms to thrive and further contribute in phytoremediation process $[11,31]$.

Table 1. Plants with phytoremediation potentials in aquatic ecosystem.

\begin{tabular}{|c|c|c|c|}
\hline Macrophyte species & $\begin{array}{l}\text { Phytoremediation } \\
\text { mechanism }\end{array}$ & Pollutant(s) & Country \\
\hline Azolla sp. & Bioaccumulation & $\mathrm{Fe}, \mathrm{Zn}, \mathrm{Cu}, \mathrm{Cr}, \mathrm{Cd}[8]$ & India \\
\hline Echhornia crassipes & $\begin{array}{l}\text { Rhizofiltration, } \\
\text { accumulation }\end{array}$ & $\begin{array}{l}\mathrm{Cd}, \mathrm{Co}, \mathrm{Cu}, \mathrm{Ni}, \mathrm{Pb}, \mathrm{Zn} \mathrm{[16]} \\
\mathrm{Fe}, \mathrm{Zn}, \mathrm{Cu}, \mathrm{Cr}, \mathrm{Cd}[8] \\
\text { TSS, nitrates, phosphates [27] } \\
\mathrm{Cd}, \mathrm{Hg}, \mathrm{Zn}, \mathrm{Ni}, \mathrm{Pb}[51]\end{array}$ & $\begin{array}{l}\text { Egypt } \\
\text { India } \\
\text { Brazil } \\
\text { Brazil }\end{array}$ \\
\hline Lemna sp. & $\begin{array}{l}\text { Phytoextraction, } \\
\text { bioaccumulation }\end{array}$ & $\begin{array}{l}\mathrm{Cd}, \mathrm{Co}, \mathrm{Cu}, \mathrm{Ni}, \mathrm{Pb}, \mathrm{Zn} \mathrm{[16]} \\
\mathrm{Cd}, \mathrm{Pb}, \mathrm{Ni}[52] \\
\text { Nitrates, phosphates [28] } \\
\mathrm{Cd}, \mathrm{Hg}, \mathrm{Zn}, \mathrm{Ni}, \mathrm{Pb}[51] \\
\mathrm{Fe}, \mathrm{Zn}, \mathrm{Cu}, \mathrm{Cr}, \mathrm{Cd}[8]\end{array}$ & $\begin{array}{l}\text { Egypt } \\
\text { Turkey } \\
\text { China } \\
\text { Brazil } \\
\text { India }\end{array}$ \\
\hline Myriophyllum sp. & Bioaccumulation & $\begin{array}{l}\text { As [12] } \\
\text { As, } \mathrm{Cd}, \mathrm{Cu}, \mathrm{Ni}, \mathrm{Pb}, \mathrm{Zn}[53]\end{array}$ & $\begin{array}{l}\text { France } \\
\text { China }\end{array}$ \\
\hline Phragmites sp. & $\begin{array}{l}\text { Rhizofiltration, } \\
\text { phytoextraction }\end{array}$ & $\begin{array}{l}\mathrm{Cd}, \mathrm{Co}, \mathrm{Cu}, \mathrm{Ni}, \mathrm{Pb}, \mathrm{Zn}[16] \\
\text { Nutrients [54] } \\
\mathrm{Cd}, \mathrm{Pb}, \mathrm{Ni}, \mathrm{Cu}, \mathrm{Zn}, \mathrm{Cr}[13]\end{array}$ & $\begin{array}{c}\text { Egypt } \\
\text { India } \\
\text { CzeckRep }\end{array}$ \\
\hline Pistia sp. & $\begin{array}{l}\text { Bioaccumulation, } \\
\text { biomonitoring }\end{array}$ & $\begin{array}{l}\mathrm{Fe}, \mathrm{Zn}, \mathrm{Cu}, \mathrm{Cr}, \mathrm{Cd}[55] \\
\mathrm{Cd}, \mathrm{Hg}, \mathrm{Zn}, \mathrm{Ni}, \mathrm{Pb}[51]\end{array}$ & $\begin{array}{l}\text { India } \\
\text { Brazil }\end{array}$ \\
\hline Salvinia sp. & $\begin{array}{l}\text { Bioaccumulation, } \\
\text { biomonitoring }\end{array}$ & $\begin{array}{l}\mathrm{Cd}, \mathrm{Pb}, \mathrm{Ni}[52] \\
\mathrm{Cd}, \mathrm{Hg}, \mathrm{Zn}, \mathrm{Ni}, \mathrm{Pb}[51]\end{array}$ & $\begin{array}{l}\text { Turkey } \\
\text { Brazil }\end{array}$ \\
\hline Spirodela sp. & $\begin{array}{l}\text { Phytoextraction, } \\
\text { bioaccumulation }\end{array}$ & $\begin{array}{l}\mathrm{Fe}, \mathrm{Zn}, \mathrm{Cu}, \mathrm{Cr}, \mathrm{Cd}[55] \\
\text { nitrates, phosphates [28] } \\
\mathrm{Fe}, \mathrm{Zn}, \mathrm{Cu}, \mathrm{Cr}, \mathrm{Cd}[8] \\
\mathrm{Cd}, \mathrm{Hg}, \mathrm{Zn}, \mathrm{Ni}, \mathrm{Pb}[51]\end{array}$ & $\begin{array}{l}\text { India } \\
\text { China } \\
\text { India } \\
\text { Turkey }\end{array}$ \\
\hline Vallisneria natans & Hyperaccumulation & $\begin{array}{l}\mathrm{Pb}[56] \\
\mathrm{As}, \mathrm{Cd}, \mathrm{Cu}, \mathrm{Ni}, \mathrm{Pb}, \mathrm{Zn}[53]\end{array}$ & $\begin{array}{l}\text { China } \\
\text { China }\end{array}$ \\
\hline
\end{tabular}

\section{Context and phytoremediation initiatives in Lebanon}

\subsection{Water quality of Lebanese water bodies}

Lebanon's water resources are harshly polluted. Major rivers have very high levels of chemical and biological pollutants and heavy metals. This is due to the uncontrolled dumping of solid wastes and chaotic release of raw domestic wastewater and industrial effluents into water streams, which poses a serious threat to public health [20, 32-34]. With the Syrian warfare (2011-2019), the unpredicted increase in Syrian refugees and Lebanese population to as much as $30 \%$ has aroused a serious extra pressure on the already delicate water resources and increased levels of pollution of fresh water bodies [35]. Daou et al. [36] investigated the water quality of four major Lebanese rivers, the Damour, Nahr Ibrahim, Kadisha, and Orontes, which are located in South, Central and North Lebanon and Bekaa Valley, respectively. The Ibrahim River was more likely to be polluted with industrial and human discharges, while the Kadisha River was severely polluted with anthropogenic human wastes. In the Litani River basin, water resources are as well heavily polluted [21]. The intensive use of fertilizers and pesticides in agricultural practices, especially during the dry season, has led to nitrates, phosphates contamination with high concentrations detected in freshwater bodies. Besides, metal contamination in the aquatic environment had a great concern $[37,38]$ owing to its environmental toxicity, abundance and persistence. In addition, water quality from the Canal 900 (which transfers water from Lake Qaraoun to irrigate land parcels in the Bekaa Plain) indicated elevated nutrient levels causing eutrophication and algal proliferation in the canal [39]. In Southern Lebanon, Awali River was found to be highly polluted with domestic sewage and solid wastes although its water is often used for irrigation [40].

In spite of noteworthy strides in the water sector in recent years remediation efforts are still limited to the implementation of wastewater treatment plants in certain areas of the country and the efficiency of the management is still 
considered poor [41]. In this context, some works on the depollution of the Litani River basin using conventional remediation methods have started. Among are some national projects funded by CNRS-L that aim to monitoring and treating the pollution in the Qaraaoun Reservoir using remote-sensing tools [42]. At the legislation level, a resolution was issued in 2012 (N 102/2012), in which a national committee for the depollution of the reservoir was formed. The committee consisted of representatives of all governmental institutions, ministries, and research centers. The committee elaborated a "road map" for a 5-year management strategy that called for an increase of the current wastewater network and the need for treated water use [44].

\subsection{Macrophytes of Lebanese waters}

A few studies about macrophytic communities were conducted in the Lebanese fresh water bodies. Abou-Hamdan et al. assessed macrophytes composition in the Upper Litani River basin and Quaraoun [43-45]. Around 27 taxa of hydrophytes, helophytes including green algae, floating and both submersed and emergent aquatic plants and terrestrial species were found. Authors concluded that successive species and macrophyte population were influenced by the heavy agricultural, urban and industrial disturbances in the Litani Upper Basin. A comprehensive study to understand the role of Lebanese macrophytic community in the functioning, restoration and management of the Lebanese aquatic ecosystem was recommended by the authors [44].

\subsection{Phytoremediation applications}

Few research studies in Lebanon were conducted on the use of macrophytes in the remediation of polluted water bodies. Zurayk et al. [46, 47] conducted two different studies to evaluate the ability of four macrophyte species native to Lebanon (Nasturtium officinale, Veronica beccabunga, Mentha longifolia and aquatica, and Cardamine uliginosa) for their potential in nickel and chromium uptake and phytoaccumulation. Plants tested showed prevalent metal removal and were tolerant to elevated concentrations of the metals. Authors concluded that these macrophytes seemed to be very good candidates for aquatic phytoremediation of $\mathrm{Ni}$ and $\mathrm{Cr}$ in contaminated Lebanese waterbodies. Ghanem et al. [29] are presently investigating the potential use of the native free floating macrophyte Lemna sp. growing naturally for in-situ phytoremediation of heavy metals from polluted watercourses in Bekaa.

In Lebanon, two main projects of phytoremediation have, so far, been conducted. These are: the CW of Upper Litani River and the reed bed wastewater treatment station in Bcharreh.

\subsubsection{Pilot constructed wetland in Kherbit Kanafar}

A constructed wetland was established in 2013 by Litani River Basin Management Support (USAID/LRBMS) and the Litani River Authority in the Upper Litani River, Kherbit Kanafar in the southern plains of the Bekaa Valley [26, 48, 49]. Directly adjacent to the Litani River, this wetland is covering an area of 2.6 ha located within the south Bekaa irrigation scheme. An inlet permits the diversion of water from the river into the wetland, while an outlet re-conducts water to its natural course, after transitory steps of bio-filtration. Macrophytes used in this bio-filtration process are the native species Sparganium erectum and Phragmites australis. Water flows slowly through the macrophytes exposed to direct sunlight within a free water surface; concurrent physical, chemical and biological processes settle solids, degrade organics while macrophytes utilize nutrients provided by the polluted water [26]. The evaluation of treatment efficiency indicated significant improvement in water quality parameters [26]. Higher removal efficiencies of nutrients were recorded with $84.6 \%$ reduction of the total inorganic nitrogen with and $83 \%$ reduction in orthophosphates in the wetland over the course of the study. Similarly, higher improvement levels with dissolved oxygen (DO) and biochemical oxygen demand (BOD) both of which witnessing changes by around $25 \%$ and $66 \%$, respectively. Abi Saab et al. [49] revealed an increase in the removal efficiency of most pollutants (about $80 \%$ ) emphasizing the importance of the wetland plants in the removal of pollutants including nutrients, pathogens and trace elements.

\subsubsection{Pilot of reed bed filter treatment in Bcharreh}

Funded by the Agence Française de Développement (AFD), this pilot treatment plant was established in 2013, with the collaboration of the union of municipalities of Bcharreh, Ministry of Energy and Water and the Council for Development and Reconstruction. It consists of a wastewater treatment pond with a vertical subsurface flow planted with Phragmites species acting as bed filters. Wastewater is discharged mechanically on top of the surface, the water flows vertically down through the biofilter media to the bottom of the basin where it is collected in a drainage pipe. This reed bed filter proved to be efficient in treating wastewater with a good purification performance recorded through the reduction of BOD, suspended solids and pathogens and the ability to nitrification due to good oxygen transfer and aerobic conditions [50].This pilot project being the first of its kind in the country will assist in assessing how phytoremediation technology functions in the Lebanese environmental conditions. However, the project is still in its early stage and research work is currently under progress to examine the effectiveness of the system over a longer period of time. 


\section{Conclusion}

Although timid, the phytoremediation applications initiated in Lebanon are hopefully promising as sustainable approach for the treatment of water pollution. Constructed wetlands could be a promising remediation technique for the restoration of the Lebanese water bodies. Nevertheless, further research must be performed to optimize constructed wetland efficiency, monitoring and management practices. It is hoped that the use of phytoremediation is promoted and its use is extended to other polluted waters in the country achieve conformity with the standards established by national legislations through a socio-economically viable approach.

\section{References}

1. OECD (2017) http://oecdinsights.org/2017/03/22/diffuse-water-pollution-growing-threat

2. K. Al-Akeel, Advances in Bioremediation and Phytoremediation (2018)

3. EPA (2016) https://www.epa.gov/sites/production/files/2016-03

4. WWF, Living Planet Report (2016)

5. L.Schweitzer, J. Noblet, Green Chemistry (2018)

6. UN (2018) https://sustainabledevelopment.un.org/content/documents/19901SDG6_SR2018_web_3.pdf

7. H. Ali, E. Khan, M. A. Sajad, Chemo. 91, 869 (2013)

8. P. K. Rai, Chem. Eco. 34, 8 (2018)

9. A. Ansari, S. Gill, F. A. Khan, M. Naeem, Eutrophication: Causes, Consequences and Control (2014)

10. P. K. Rai, 184, 421 (2012)

11. A. Guittonny-Philippe, V. Masotti, P. Höhener, J. L. Boudenne, J. Viglione, I. Laffont-Schwob, Envi. Inter. 64, 1 (2014)

12. M. Krayem, V. Deluchat, M. Rabiet, K. Cleries, J.F. Lenain, Z. Saad, V. Kazpard, P. Labrousse, Chemo. 147, 141 (2016)

13. J. Vymazal, T. Brezinová, Chem. Engi. J. 290, 232 (2016)

14. Q. Wang, Y. Hu, H. Xie, Z. Yang, Water, 10, 678 (2018)

15. M. A Fawzy, N. Badr, A. El-Khatib, A. Abo-El-Kassem, Environ. Monit. Assess. 184, 1753 (2012)

16. K. A. Kamel, Mid. Eas. J. Sci. Res. 14, 12 (2013)

17. A. Allam, A. Tawfik, A. El-Saadi, A. Negm, Des. Wat. Treat. 57, 459 (2016)

18. M. W. Shammout, H. Zakaria, Eco. Engi. 83, 71 (2015)

19. M. S. Al-Khafaji, F. H. Al-Ani, A. F. Ibrahim, J. Civ. Eng. 22, 4 (2018)

20. N. Nehme, C. Haidar, The Litani River, Lebanon: An Assessment and Current Challenges (2018)

21. A. Shaban, M. Hamzé, The Litani River, Lebanon: An Assessment and Current Challenges(2018)

22. MOE /WB, Cost Assessment of Environmental Degradation (2003)

23. E. Pilon-Smits, Annu. Rev. Pla Biol.56, 15 (2005)

24. I. Herath, M. Vithanage. Phytoremediation: Management of Environmental Contaminants (2015)

25. M. Wang, D. Q. Zhang, J. W. Dong, S. K. Tan, J. enviro. Sci. 57, 293 (2017)

26. N. Amacha, F. Karam, M. Jerdi, P. Frank, E. Viala, Envi. Poll. Cli. 1, 119 (2017)

27. J. A. S. Osti, M. N. P. Henares, A. F. M. Camargo, 49, 3468 (2018)

28. G. Chen, Y. Fang, J. Huang, Y. Zhao, Q. Li, F. Lai, Y. Xu, X. Tian, K. He, Y. Jin, L. Tan, H. Zhao. Roy. Soc. Chem. 8, 17927 (2018)

29. H. Ghanem, S. Korfali, L. Chalak, H. AbouHamdan, S. Baydoun. 23th LAAS International Science Conference (2017)

30. V. Kastratovic., S. Krivokapić, D. Đurović, N. Blagojević, J. Serbi, Chem. Soc. 78, 8 (2013)

31. O. Shelef, A. Gross, S. Rachmilevitch, Water, 5, 405 (2013)

32. A. Houri, S. W. El Jeblawi, J. Wat. Heal. 5, 4 (2007)

33. AFED (2014) http://www.afedonline.org/en/inner.aspx?contentID=1089

34. A. Atoui, H. Hafez, K. Slim, Water Envi. J. 27, 42 (2013)

35. MoE/EU/UNDP, Lebanon Environmental Assessment of the Syrian Conflict \& Priority interventions (2014)

36. Daou, M. Salloum, B. Legube, A. Kassouf, N. Ouaini, Enviro. Moni. Ass. 190, 485 (2018)

37. C. Haydar, N. Nehme, S. Awad, B. Koubayssi, M. Fakih, A. Yaacoub, J. Toufaily, F. Villieras, T. Hamieh, J. Envi. Earth Sci. 4, 87 (2014)

38. S. Korfali, M. Jurdi, N. Amacha, J. Envi. Sci. Eng. 3, 55 (2014)

39. N. Amacha, M. Saadeh, F. Karam, R. Eter, R. Jomaa, A. Koubaissi, S. Baydoun, Int. J. Rec. Sci. Res. 6, 2 (2015)

40. S.I. Korfali, M. Jurdi, Euro.Wat. 35, 3 (2011)

41. GEF/World Bank/Plan Bleu, Strategic Environmental Assessment for the New Water sector Strategy for Lebanon (2015)

42. T. Darwich, A. Shaban, M. Hamzé, TheLitani River, Lebanon: An Assessment and Current Challenges (2018)

43. H. Ismail, H. Abou-Hamdan, A. Kobaissi, G. Khalaf, A. Cazaubon, J. Haury, Eco. Medit. 35, 31(2009)

44. H. Abou-Hamdan, H. Ismail, R. Mouawad, M. Shehadi, A. Kobaissi, Inter. J. Inno. Res. Sci. Engi, 2, 430 (2014a)

45.H. Abou-Hamdan, H. Ismaïl, N. Amacha, L. Chalak, R. Jomaa, M. Kamar, A. Kobaissi, S. Baydoun, Inter. J. Sci. Res. 3, 1132 (2014b)

46. R. Zurayk, B. Sukkariyah, R. Baalbaki, D. Abi Ghanem, Inter. J. Phyto. 3, 3 (2001)

47. R. Zurayk, B. Sukkariyah, R. Baalbaki, D. Abi Ghanem, Water, Air, Soil Poll. 139, 355 (2002).

48. LRMBS, IRG, Lebanon (2012)

49. M. T. Abi Saab, D. Jammoul, H. Makhlouf, S. Fahed, N. Lebbous, C. Hajjar, R. Abi Saad, M. Younes, M. Hajj, M. Todorovic. Water Envi. J. 32, 508 (2018) 
50. pS-Eau (2018) https://www.pseau.org/fr/liban

51. C. B. de Souza, G. R. Silva, Bioengineering (2018)

52. Z. Leblebici, M. Kari, V. Yalcin. Rom. Biotech. Let. (2017)

53. G. Lu, B. Wang, C. Zhang, S. Li, J. Wen, G. Lu, C. Zhu, Y. Zhou, Inter. J. Phyto. 20, 8 (2018)

54. K. B. Jethwa, S. Bajpai, J. Chem. Pharm. Sci. 2, 115 (2016)

55. V. K. Mishra, B.D. Tripathi, Biores. Tech. 99, 7091(2008)

56. W. Xing H. Wu, B. Hao, W. Huang, G. Liu, Env. Sci. Tech. 47, 4695 (2013) 